Article

\title{
Structure and tribological properties of wear-resistant layers produced in process of plasma powder surfacing
}

\author{
Tomasz Poloczek ${ }^{1, *}$, Artur Czupryński ${ }^{1}$, Marcin Żuk ${ }^{1}$, Marek Chruściel ${ }^{1}$ \\ ${ }^{1}$ Silesian University of Technology, Poland \\ Artur Czupryński Ph.D. Eng., artur.czuprynski@polsl.pl; \\ Marcin Żuk M.Sc. Eng., marcin.zuk@polsl.pl; \\ Marek Chruściel Eng., marek.chrusciel@polsl.pl; \\ * Correspondence: Tomasz Poloczek M.Sc. Eng., tomasz.poloczek@polsl.pl
}

Received: 09.04.2019; Accepted: 03.05.2019

\begin{abstract}
The following study presents the results of wear-resistant layer made of Ni-Cr-Si-B-Fe-C+WC alloy in the form of metallic powder on the AISI 4715 steel. Hardness and abrasion resistance tests were performed in accordance to PN-EN ISO 6508-1:2016 and ASTM G65-00 standards. Obtained data were compared to the abrasion resistant steel produced by Swedish manufacturer. Microscopic observations were made to determine the structure of obtained layer and base material using Olympus SZX9 stereoscopic light microscope. In order to determine the chemical composition of microregions, X-ray microanalysis researches were carried out.
\end{abstract}

Keywords: plasma welding; powder transferred arc welding; PTA; abrasive wear

\section{Introduction}

The creation of new solutions in the field of construction of machines and devices for the industry requires the implementation of innovative engineering materials characterized by high properties regarding resistance to tribological wear. Tribological wear processes are particularly important for the mining industry, processing of mineral raw materials and during machine operation in the construction industry. In the case of parts of these machines, regeneration or replacement is often required. The most commonly used materials for work in this type of environment are wear-resistant Hardox, Hardstal and Miilux steels. They owe their high strength properties to an appropriate heat treatment with a strictly controlled chemical composition, but the prices of these materials are relatively high. Taking into account the economic factor, one of the legitimate regeneration techniques is the use of surfacing methods that enable the production of preventive top layers on elements without the need to replace them. Proper selection of materials and parameters of the surfacing technology allows for reconstruction of the geometry of regenerated elements while increasing their operational life, thus eliminating costly machine repairs and downtime. In many cases, the surfacing method is also used directly in the design of machine parts to ensure high strength and resistance to work in the environment of erosive, abrasive or corrosive wear, which are often interrelated. For this purpose, the most commonly used methods are Flux Cored Arc Welding (FCAW) or Plasma Powder Transferred Arc Welding (PPTAW). The layers obtained in these processes, thanks to the carefully selected chemical composition, enable to obtain an appropriate structure and carbide precipitates usually characterized by much higher properties regarding resistance to tribological wear compared to standard materials intended for operation in a given type of environment $[1 \div 13]$.

\section{Own research}

The aim of the conducted research was to determine the resistance to abrasive wear of the metalmineral type, hardness and structure of the plasma powder surfaced wear-resistant layer made on the base of low-alloy steel AISI 4715 (Table I). For this purpose, a station equipped with a Castolin Eutronic GAP 2001DC device with an E150P welding clamp for manual plasma powdersurfacing was used. The material used to make the surface layer was Ni-Cr-Si-B-Fe-C alloy with the addition of spherical tungsten carbide in the form of a metallic powder (Table II). The material from low-alloy structural steel was subjected to a manual plasma surfacing using the tested powder and technological parameters given in table III. 
Table I. Chemical composition of base material

\begin{tabular}{ccccccccc}
\hline $\begin{array}{c}\text { Designation } \\
\text { of the steel }\end{array}$ & $\mathbf{C}$ & $\mathbf{M n}$ & $\mathbf{S}_{\max }$ & $\mathbf{P}_{\max }$ & $\mathrm{Si}$ & $\mathbf{C r}$ & $\mathbf{M o}$ & $\mathbf{N i}$ \\
\hline AISI 4715 & $0.12 \div 0.18$ & $0.65 \div 0.95$ & 0.015 & 0.015 & $0.15 \div 0.35$ & $0.40 \div 0.70$ & $0.45 \div 0.60$ & $0.65 \div 1.00$ \\
\hline
\end{tabular}

Table II. Chemical composition of Ni-Cr-Si-B-Fe-C+WC metal powder

\begin{tabular}{|c|c|c|c|c|c|c|c|}
\hline \multirow{3}{*}{$\begin{array}{c}\text { Sintered tungsten } \\
\text { carbide }-68 \% \text { powder }\end{array}$} & \multicolumn{7}{|c|}{ Percentage concentration [wt.\%] } \\
\hline & \multicolumn{2}{|c|}{ WC } & \multirow{2}{*}{\multicolumn{2}{|c|}{$\begin{array}{c}\text { Co } \\
6.0 \div 7.0\end{array}$}} & \multicolumn{2}{|l|}{$\mathbf{F e} \max$} & $\mathbf{T i}_{\max }$ \\
\hline & \multicolumn{2}{|c|}{93.0} & & & \multicolumn{2}{|l|}{0.25} & 0.04 \\
\hline \multirow{3}{*}{$\begin{array}{c}\text { Matrix } \\
-32 \% \text { powder }\end{array}$} & \multicolumn{7}{|c|}{ Percentage concentration $\%$} \\
\hline & $\mathrm{Cr}$ & Si & B & $\mathrm{Fe}$ & $\mathbf{P}_{\max }$ & $\mathrm{C}$ & $\mathrm{Ni}$ \\
\hline & $14.0 \div 17.0$ & $3.4 \div 4.9$ & $3.0 \div 3.4$ & $2.4 \div 4.6$ & 0.3 & $0.65 \div 0.80$ & $\sim 70$ \\
\hline
\end{tabular}

Table III. Parameters of manual plasma powder surfacing process

\begin{tabular}{cccc}
\hline $\begin{array}{c}\text { Current intensity [A] } \\
50\end{array}$ & $\begin{array}{c}\text { Plasma arc voltage [V] } \\
\text { Electrode type } \\
\text { Tungsten }\end{array}$ & $\begin{array}{c}\text { Diameter of the electrode } \\
\text { [mm] }\end{array}$ \\
\hline $\begin{array}{c}\text { Diameter of the plasma } \\
\text { nozzle opening [mm] }\end{array}$ & Plasma gas flow rate $[1 / \mathrm{min}]$ & $\begin{array}{c}\text { Shielding gas flow rate } \\
{[1 / \mathrm{min}]}\end{array}$ & $\begin{array}{c}\text { Flow rate of the gas } \\
\text { transporting the powder } \\
{[1 / \mathrm{min}]}\end{array}$ \\
2.2 & 0.5 & 8.0 & 2.1 \\
\hline
\end{tabular}

\section{Testing the resistance to abrasive wear of the working layer of wear-resistant material}

The procedure for testing the resistance of the surfaced wear-resistant layer to metal-mineral abrasive wear was carried out in accordance with the recommendations contained in ASTM G65-00, Procedure A. The test stand is shown in figure 1.
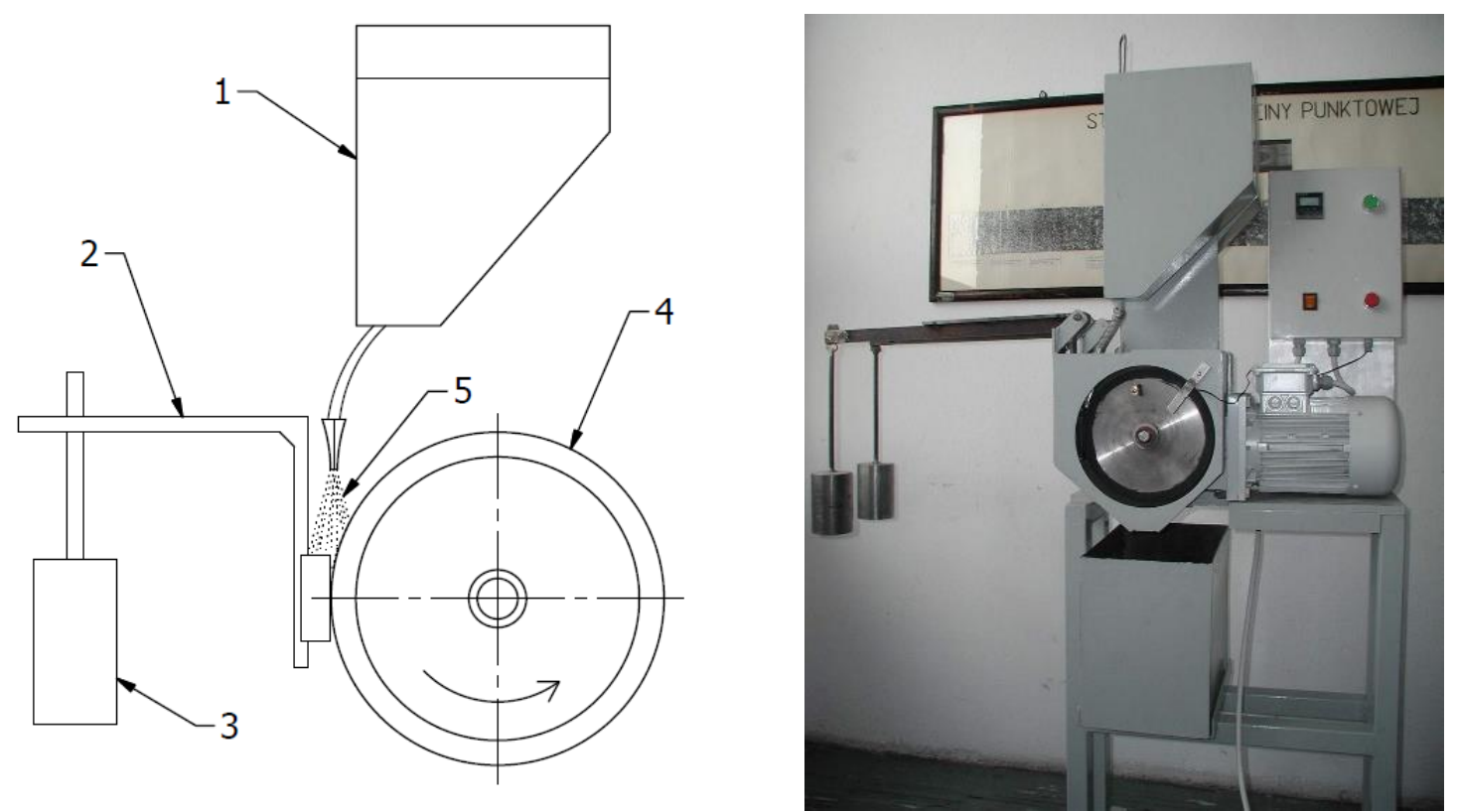

Fig. 1. Abrasive wear test stand, according to ASTM G65-00, Procedure A: 1 - abrasive container, 2 - sample holders, 3 - weights, 4 - rubber wheel, 5 - abradant [5]

In order to carry out the wear test, $76 \times 25 \mathrm{~mm}$ samples were prepared, which were cut from the middle part of the surfaced sheet. Before the tests, the wear-resistant layer was subjected to grinding to obtain an even work surface. During the test, the rubber wheel of the testing machine made 6000 revolutions 
at the friction wheel clamped to the tested material with a force of $130 \mathrm{~N}$. According to the requirements imposed by ASTM G65-00, Ottawa A.F.S. Testing Sand 50-70 was used as the abradant, whose flow rate during the test was $335 \mathrm{~g} / \mathrm{min}$. In order to determine the resistance to abrasive wear, a volumetric weight loss was determined, calculated on the basis of the average loss of the padding weld's mass after the wear test and the density of the surfaced layer. For this purpose, the RADWAG WAX 60/220 laboratory scale was used, weighing the samples before and after the test with an accuracy of $0.0001 \mathrm{~g}$. To determine the density of surface layers of wear-resistant materials, a hydrostatic method was used, which consisted in measuring the mass of samples in the air and then on liquids with known properties. The dependence (1) was used to calculate the volume loss of the mass.

$$
\text { Volume loss of mass }\left[\mathrm{mm}^{3}\right]=\text { Mass loss }[\mathrm{g}] \text { : Density }\left[\mathrm{g} / \mathrm{cm}^{3}\right] \text { x } 1000
$$

Obtained data on resistance to abrasive wear of the metal-mineral type were referred to the reference material made of wear-resistant sheet from the Swedish manufacturer with a declared hardness of $40 \div 46$ HRC [14]. The test results are presented in Table IV, and the view of the surface of the samples after the test is shown in figure 2.

Table IV. Abrasive wear test results of Ni-Cr-Si-B-Fe-C+WC layer in relations to abrasion resistant steel

\begin{tabular}{ccccccc}
\hline & \multicolumn{2}{c}{ Mass of the sample $[\mathrm{g}]$} & Mass & Density \\
Type of material & $\begin{array}{c}\text { Before } \\
\text { the test }[\mathrm{g}]\end{array}$ & $\begin{array}{c}\text { After } \\
\text { the test }[\mathrm{g}]\end{array}$ & $\begin{array}{c}\text { loss } \\
{[\mathrm{g}]}\end{array}$ & $\begin{array}{c}\text { Volume loss } \\
{\left[\mathbf{g m m}^{3}\right]}\end{array}$ & $\begin{array}{c}\text { Resistance to } \\
\text { abrasion in regard } \\
\text { to the reference } \\
\text { material }\end{array}$ \\
\hline $\begin{array}{c}\text { Surfaced layer } \\
\text { Reference material }\end{array}$ & 153.3902 & 153.2222 & 0.1680 & 8.8895 & 18.8987 & 9.41 \\
\hline
\end{tabular}

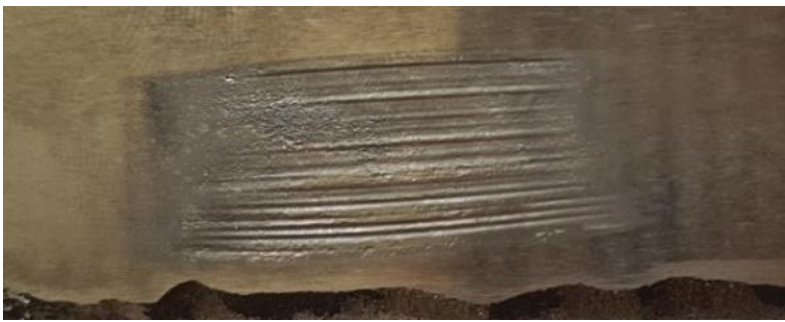

(a)

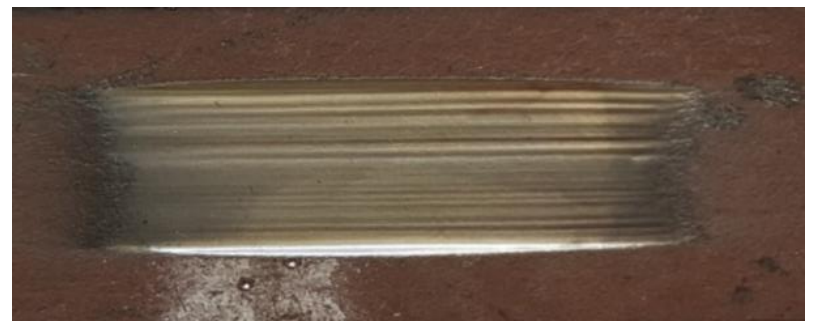

(b)

Fig. 2. Surface view after abrasive wear test according to ASTM G65-00, Procedure A; a) surfaced layer, b) wearresistant steel

\section{Hardness measurements of wear-resistant layer and reference material}

Measurements of hardness on the surface of the wear-resistant layer and the reference material were carried out using the Rockwell method on the $\mathrm{C}$ scale in accordance with the guidelines contained in PNEN ISO 6508-1: 2014-12. The 600MBDL hardness tester from Innovatest was used for this purpose, using a pressure of $1471 \mathrm{~N}$ during the test at a standard load time of 5 seconds. Five measurements were made along one measuring line on the surface of the tested element, and then the average value from the obtained measurement results was calculated (Table V).

Table V. Hardness results of wear-resistant layer and reference material

\begin{tabular}{ccccccc}
\hline & \multicolumn{3}{c}{$\begin{array}{c}\text { Hardness [HRC] } \\
\text { Measurement number }\end{array}$} & \multicolumn{2}{c}{$\begin{array}{c}\text { Average } \\
\text { value }\end{array}$} \\
\hline Padding weld & $\mathbf{1}$ & $\mathbf{2}$ & $\mathbf{3}$ & $\mathbf{4}$ & $\mathbf{5}$ & 57.2 \\
Reference material & 55 & 52 & 58 & 61 & 60 & 42.6 \\
\hline
\end{tabular}

In the next stage, hardness measurements of the plasma powder surfaced layer in the cross-section along two parallel measurement lines $10 \mathrm{~mm}$ apart from each other were carried out. For this purpose, the Wilson-Wolpert Tester 401MVD was used, conducting the test with a normative load of $9.81 \mathrm{~N}$ and the indenter's interaction time equal to $15 \mathrm{~s}$. The results obtained from the measurements are shown in table VI. 
Table VI. Cross-section Vicker's hardness results of wear-resistant layer

\begin{tabular}{cccc}
\hline & Hardness [HV10] & \multicolumn{2}{c}{ Measuring line } \\
$\begin{array}{c}\text { Measurement } \\
\text { number }\end{array}$ & Place of measurement & $\mathbf{1}$ & $\mathbf{2}$ \\
\hline 1 & & 1228.9 & 1181.0 \\
2 & Padding weld & 623.8 & 729.8 \\
3 & & 1287.5 & 728.3 \\
4 & & 663.4 & 1210.3 \\
\hline 5 & Transition zone & 729.0 & 847.2 \\
\hline 6 & & 460.5 & 464.2 \\
7 & Heat affected zone & 457.2 & 468.8 \\
9 & & 464.1 & 463.0 \\
\hline 10 & & 432.5 & 441.8 \\
11 & & 450.1 & 439.7 \\
12 & Substrate material & 444.2 & 450.6 \\
13 & (AISI 4715) & 443.1 & 444.5 \\
\hline
\end{tabular}

\section{Metallographic examinations}

The analysis of metallographic microscopic observations made it possible to determine the structures obtained in the padding weld, the transition zone and the substrate. The tests were carried out on a Olympus SZX9 stereoscopic microscope. The structure of the substrate consists of low-carbon martensite tempered with lower bainite (Fig. 3). In the austenitic matrix of the padding weld made with the Ni-Cr-Si$\mathrm{B}-\mathrm{Fe}-\mathrm{C}+\mathrm{WC}$ powder, intermetallic clusters of various sizes were found (Fig. 3c). The obtained precipitations of sintered tungsten carbide with a cobalt matrix takes on the globular nature of occurrence along the entire surface of the surfaced layer.

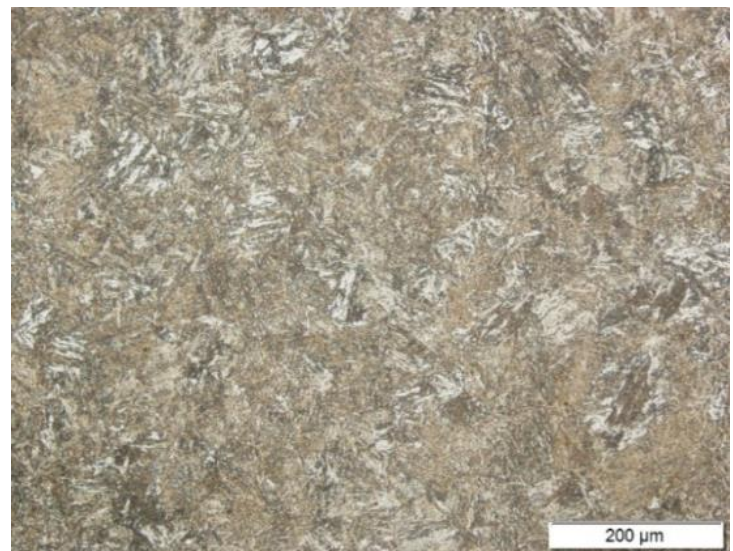

(a)

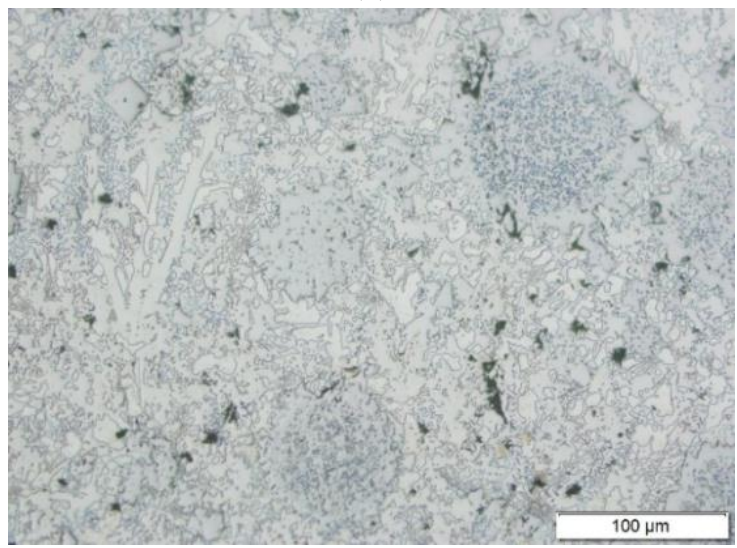

(c)

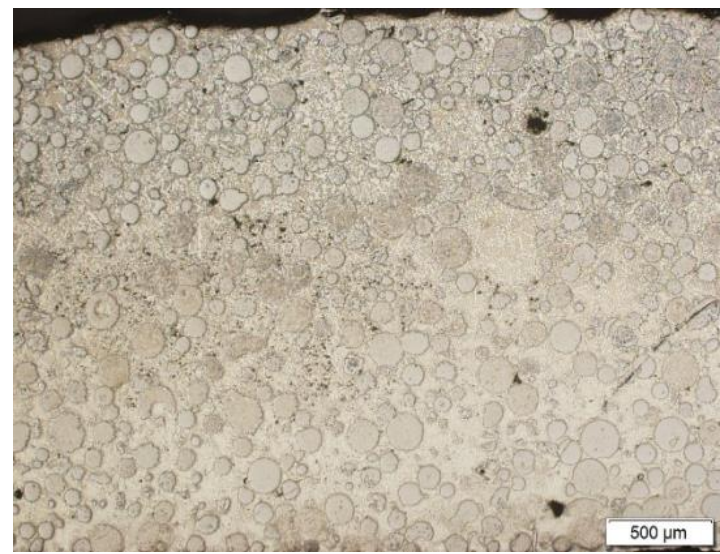

(b)

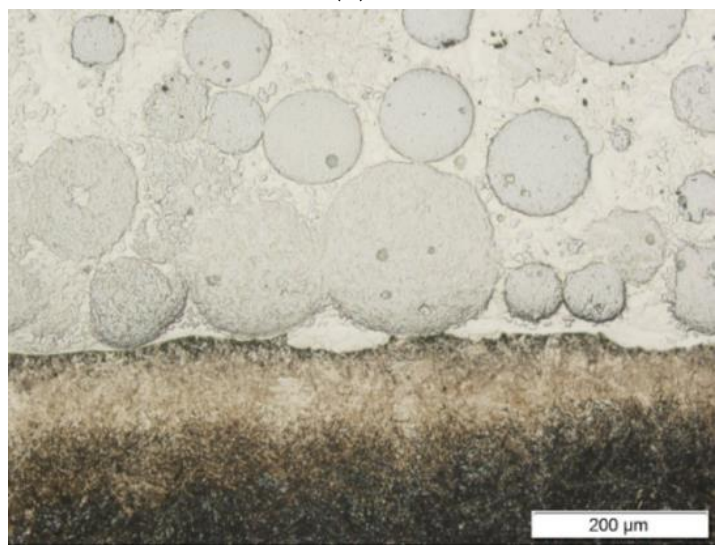

(d)

Fig. 3. Structure of wear-resistant layer; a) base material structure, b) surface layer microstructure, c) intermetallic phases in the middle part of surface layer, $d$ ) transition zone microstructure 


\section{Tests with the use of a scanning electron microscope}

The analysis of the structure using the scanning electron microscope allowed to determine the chemical composition in a qualitative and quantitative manner of the padding weld's matrix micro-areas and the precipitates of various sizes appearing in it. The results of the investigated areas are shown in figure 4. In the structure of the padding weld, morphologically diverse intermetallic phases consisting predominantly of tungsten carbide and in smaller amounts of chromium and iron carbides were observed. The matrix revealed the presence of fine intermetallic phases consisting of tungsten, iron and cobalt taking different shapes.
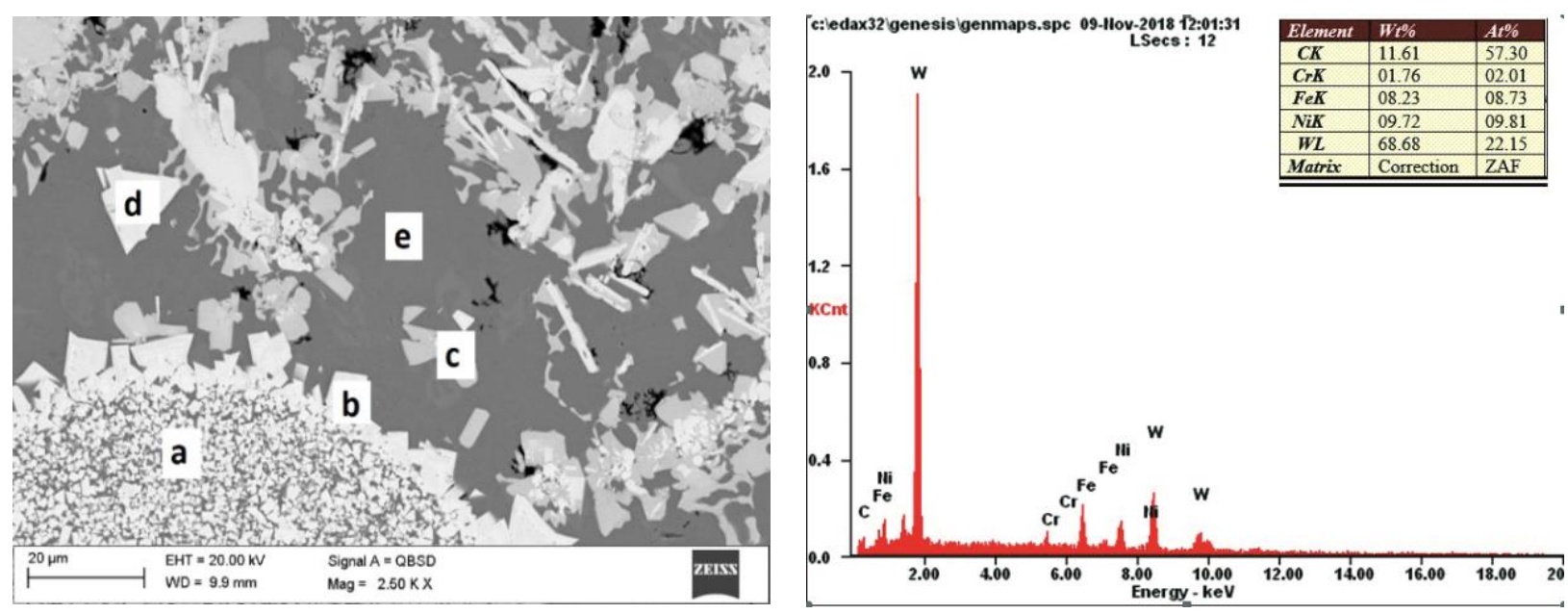

(a)

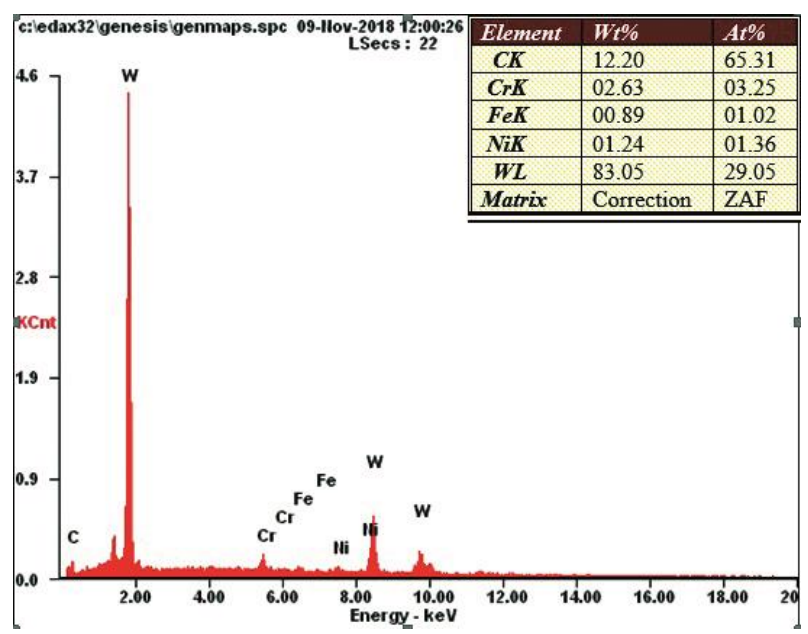

(b)

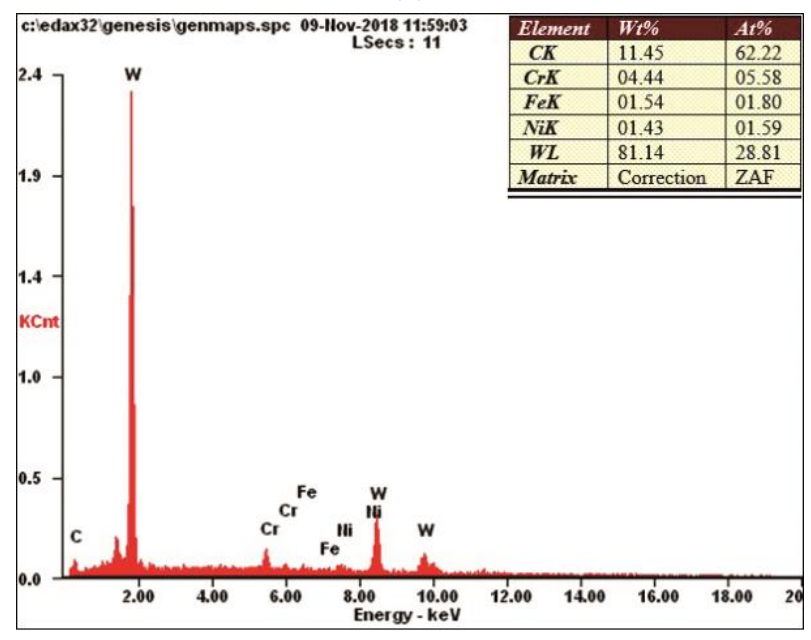

(c)
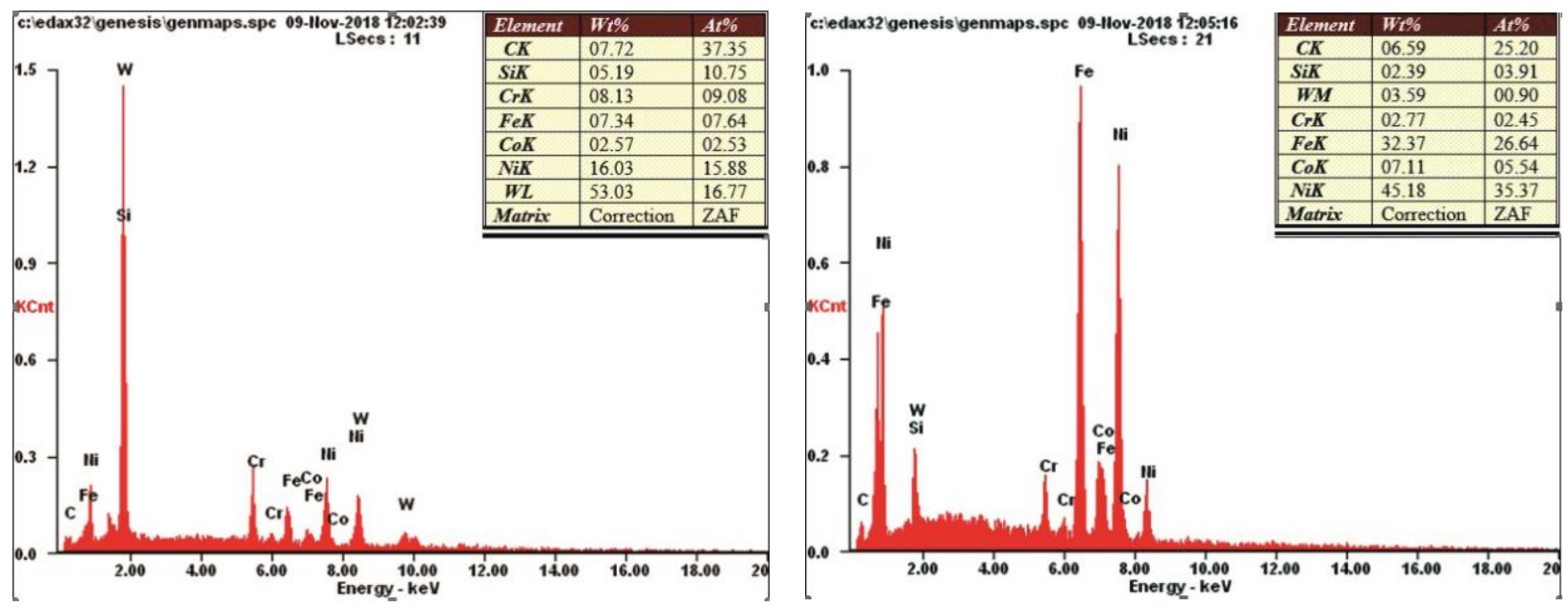

(d)

(e)

Fig. 4. Microanalysis results of chemical composition from areas marked on the microphotography 
In the near-surface zone of the padding weld, the described phases occur in spherical regions with diameters of approx. $100 \mu \mathrm{m}$, increasing their dimensions up to $200 \mu \mathrm{m}$ in the middle part of the zone, which is related to the rate of heat dissipation in particular areas of the padding weld. The size of existing intermetallic phases in the studied areas is approx. $2 \mu \mathrm{m}$, while the precipitations around these areas reach sizes in the range of $3 \div 8 \mu \mathrm{m}$.

The microanalysis investigations of fine phases located in the spherical shaped areas allowed to reveal their chemical composition, which consists of carbon, chromium, iron, nickel and tungsten. The atomic concentration of individual elements may indicate the occurrence of complex type tungsten carbides $(\mathrm{WxMyC})$, while the larger size phases formed around globular clusters are characterized by concentrations of tungsten corresponding to tungsten carbide (W29C65). Matrix analysis by X-ray microanalysis reveals the presence of increased iron atomic concentration (26.64\% at) and nickel (35.37\% at) in its area.

\section{Summary}

Obtained results of research on the layer surfaced manually by the plasma powder method on a nickel matrix with a high amount of carbide precipitates show an approximately nine-fold increase in resistance to abrasive wear of the metal-mineral type in relation to the wear-resistant steel of a Swedish manufacturer

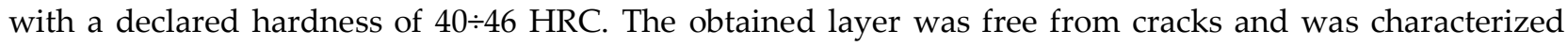
by a small depth and correct shape of the penetration, demonstrating the properly conducted technology of the manual plasma powder surfacing process. The obtained data from the conducted tests confirm the beneficial effect of the padding weld's chemical composition on the increase of hardness and resistance to abrasive wear in relation to the properties of standard steel used in tribological wear conditions. Proper selection of parameters for conducting the welding process determines the formation in the weld structure of complex intermetallic phases, consisting mainly of tungsten carbides type $\mathrm{W} 2 \mathrm{C}$, ensuring high hardness of the surface layer (about $57 \mathrm{HRC}$ ).

\section{Resources}

[1] Bober M., Senkara J., Study of the structure of composite coatings Ni-WC deposited by plasma transferred arc. Welding Technology Review, 2016, Vol. 88 (5), 67-70. [CrossRef]

[2] Czupryński A., Kik T., Melcer M., Comparison of abrasion resistance of wear plates. Welding Technology Review, 2018, Vol. 90 (5), 28-36. [CrossRef]

[3] Ulutan M., Celik O.N., Kılıçay K., Er U., Microstructure and wear behaviour of plasma transferred arc (PTA)deposited FeCrC composite coatings on AISI 5115 steel. Journal of Materials Processing Technology, 2016, Vol. 236, 26-34. [CrossRef]

[4] Hou Q.Y., Gao J.S., Zhou F., Microstructure and wear characteristics of cobalt-based alloy deposited by plasma transferred arc weld surfacing. Surface and Coatings Technology, 2005, Vol. 194, 238-243. [CrossRef]

[5] Adamiak M., Górka J., Kik T., Comparison of abrasion resistance of selected constructional materials. Journal of Archives of Materials Science and Engineering, 2009, Vol. 37(2), 375-380. [Hyperlink]

[6] Tao S., Liang B., Ding C., Liao H., Coddet C., Wear characteristic of plasma-sprayed nanostructured yttria partially stabilized zirconia coatings. Journal of Thermal Spray Technology, 2005, Vol. 14, 518-523. [CrossRef]

[7] Xiong Y., Lin D., Zheng Z., Li J., Deng T., The Effect of Different Arc Currents on the Microstructure and Tribological Behaviors of $\mathrm{Cu}$ Particle Composite Coating Synthesized on GCr15 Steel by PTA Surface Alloying. Metals, 2018, Vol. 8(12), 984. [CrossRef]

[8] Jiang J., Xiao G., Wang Y., Liu Y., Tribological Behavior of Nano-Sized SiCp/7075 Composite Parts Formed by Semisolid Processing. Metals, 2018, Vol. 8, 148. [CrossRef]

[9] Wang C.-R., Deng K.-K., Bai Y., Microstructure and Mechanical and Wear Properties of Grp/AZ91 Magnesium Matrix Composites. Materials, 2019, Vol. 12, 1190. [CrossRef]

[10] Xu X., Ding H., Xia C., Zou J., Wang Y., Effect of Brazing Temperature on the Microstructure and Chosen Properties of WC-10Ni/NiCrBSi Composite Coatings Produced by Vacuum Cladding from Flexible Coated Cloths. Coatings, 2019, Vol. 9, 214. [CrossRef]

[11] Xu L., Song J., Zhang X., Deng C., Liu M., Zhou K., Microstructure and Corrosion Resistance of WC-Based Cermet/Fe-Based Amorphous Alloy Composite Coatings. Coatings, 2018, Vol. 8, 393. [CrossRef]

[12] Wohaibi S.A., Mohammed A.S., Laoui T., Hakeem A.S., Adesina A.Y., Patel F., Tribological Characterization of Micron-/Nano-Sized WC-9\%Co Cemented Carbides Prepared by Spark Plasma Sintering at Elevated Temperatures. Materials, 2019, Vol. 12, 920. [CrossRef] 
[13] Aristizabal M., Ardila L.C., Veiga F., Arizmendi M., Fernandez J., Sánchez J.M., Comparison of the friction and wear behaviour of WC-Ni-Co-Cr and WC-Co hardmetals in contact with steel at high temperatures. Wear, 2012, 280-281, 15-21. [CrossRef]

[14] Materials of SSAB Special Steels.

(C) 2019 by the authors. Submitted for possible open access publication under the terms and conditions of the Creative Commons Attribution (CC BY) license (http://creativecommons.org/licenses/by/4.0/). 